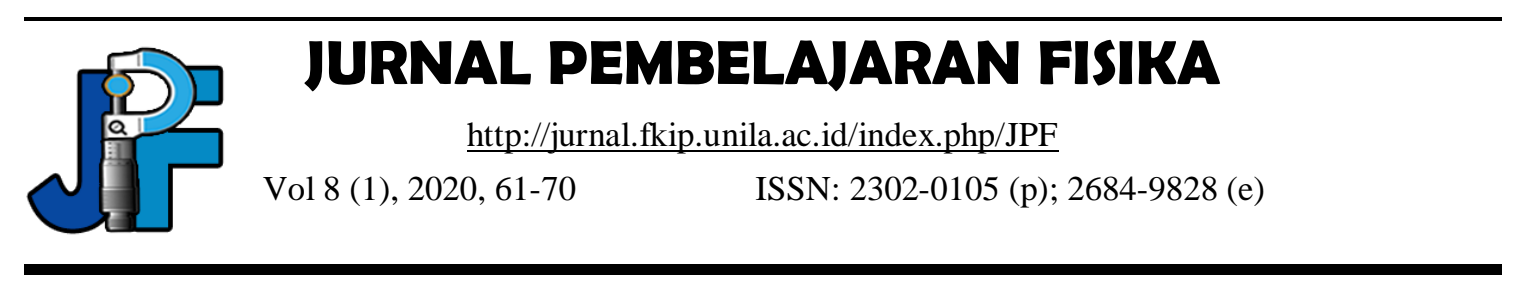

\title{
Augmented Physics' Lab: Magnetic Field Use Virtual Learning Media for 21st Century Students
}

\author{
Dadan Sumardani $^{1}$, Agustiani Putri ${ }^{1 *}$, Zulri Ramadhan ${ }^{1}$, Dewi Muliyati ${ }^{1}$, Fauzi Bakri ${ }^{1}$ \\ ${ }^{1}$ Universitas Negeri Jakarta, Indonesia \\ *e-mail: agustianiputri15@gmail.com
}

\begin{abstract}
The $21^{\text {st }}$ century has brought a paradigm change that shifts conventional learning towards technology-based learning. PISA data shows that Indonesia only achieved a score of 382, while TIMSS stated that the percentage of correct answers to the problem of understanding was always higher than the matter of application. This indicates that HOTS students in Indonesia have not yet developed optimally. This investigation intends to create worksheets for students implemented by augmented reality on magnetic field substance. This investigation was development research which used the Dick and Carey method. The product can display 3Dimensional simulations. According to an investigation, the validation result of the students' worksheets already met the criteria very well in terms of material with a percentage of $95 \%$, in terms of media with a percentage of $86.8 \%$ and terms of learning with a percentage of $81 \%$, and product trials by teachers with a percentage of $98 \%$. Meanwhile, trials of students obtained a Ngain result of 0.64 which interpreted an increase in students' high-level thinking skills in the medium level. Therefore, it could be assumed that augmented physics' lab has been suitable for students' higher-order thinking skills.
\end{abstract}

Keywords: Augmented Reality, HOTS, Virtual Learning

DOI: http://dx.doi.org/10.23960/jpf.v8.n1.202007 


\section{INTRODUCTION}

Mastery of science and technology is now an important key in facing challenges in the future. The $21^{\text {st }}$ century has brought a paradigm shift to the curriculum, media and technology. One of the changes that occurred is the shift of conventional learning towards technology-based learning (Yusuf, Widyaningsih, \& Purwati, 2015). Students need to learn to use technology that is essential for daily life and to be productive in the workplace. In addition, pedagogy and training in the context of $21^{\text {st }}$ century, especially in the 2013 curriculum, is that students learn material through examples, applications and real-world experiences both inside and outside of school (Noss, 2012). In order for these demands to be implemented as curriculum implementation in 2013, it is necessary to involve the use of technology in an appropriate, sustainable, and affordable manner.

Data from the Program of International Student Assessment shows that aspects of Indonesian science were placed $38^{\text {th }}$ in a series in 2000 and 2003 among an average of 393 and 395 , and rated $50^{\text {th }}$ in 2006 by a record of 393, whereas in 2012 it ranked $64^{\text {th }}$ from 65 countries by a number of 382 . This illustrates that the score of Indonesia's scientific achievement is significantly below the international average set at a score of 500 (Salsabila, Rahayu, Kharis, \& Putri, 2019). This is also supported by Trends in Mathematics and Science Study data which the result in the field of physics show that Indonesia scored 397 where this amount is subsequently the international score of 500 . The average percentage of correct answers for science content and cognitive domains, the percentage of correct answers in the matter of understanding is always higher compared to the percentage on the matter of application and reasoning (Ramalisa \& Pasaribu, 2015).

The concept of $21^{\text {st }}$ century learning must be applied to learning physics both in the classroom and through laboratory activities. One of the important activities in the laboratory environment is practicum. Several studies have successfully explored the benefits of practicum, including practicum which can be used as a vehicle to construct, reconstruct, verify, and strengthen scientific knowledge (Tobin, 1990). Practical activities can train basic skills in experimenting and scientific methods (Hofstein \& Lunetta, 2013). Practicum activities are also able to stimulate the development of low level thinking skills towards higher level thinking (Deacon \& Hajek, 2010). Practicum is not limited only by activities in the laboratory. Praktium can be done well by using simulations of simplifying real conditions into simple concepts, such as the simulation of relativity theory using virtual reality (Sumardani et al, 2020) and lorentz simulation use augmented reality (Bakri et al, 2019).

Considering the benefits and importance of practicum activities, it is appropriate for schools to complete laboratory facilities and infrastructure according to needs standards. Students also need to be involved in a variety of experiences so that they are able to construct and obtain a variety of scientific knowledge, skills and attitudes. However, in general the practicum conducted has not been able to provide benefits as expected due to various limitations and obstacles. The main obstacles that are commonly found are the limitations of practicum equipment, the difficulty of teachers in designing and implementing practicum (D. H. Putri, Sutarno, \& Risdianto, 2014) and practicum activities which are still conventional (Malik, Handayani, \& Nuraini, 2015). In conventional practicum, teachers have difficulty in controlling the proportion of 
hands-on and minds-on activities, as a result practicum activities are only dominant in motor activities, while cognitive activity is neglected. Conventional practicums become less able to practice HOTS (Hodson, 2006). The capability to analyze at higher level can be equipped by practicum activities (Majzub, 2013).

The low learning outcomes of physics can be seen from the absorptive capacity of high school students towards physics materials tested at UNBK in 2019 that require higher-order thinking skills. One of the materials with low absorption is magnetic field of $51.23 \%$. At the level of DKI Jakarta Province, the highest percentage of absorptive capacity of high school students in magnetic field material was $67.05 \%$ in Central Jakarta City, while the lowest percentage of absorptive material in magnetic field material was 59.73\% in East Jakarta City (BSNP, 2019). This indicates that students in Indonesia are still weak in dealing with questions that require high-level thinking, including critical thinking on magnet field material, especially high school students in the East Jakarta area.

Development of hots in the educational environment continues to be done in a variety of efforts, such as intersecting with learning models (Putri, Sumardani, Rahayu, \& Hajizah, 2020), also with learning tools such as worksheets (Fauzi Bakri et al., 2019; Sumardani et al, 2020), and books (Permana, Bakri, \& Chaerunnisa, 2019). The many challenges and obstacles in practicum activities encourage the use of new strategies. Sutrisno suggested the use of augmented reality as an alternative to practicum activities, especially for abstract concepts that would not be possible in the laboratory due to the absence or limitations of practicum equipment (Asyhar, Mujasam, Yusuf, \& Widyaningsih, 2017). Practicum using augmented reality technology can maximize the minds-on activities of students in practicum and is more interactive for students (Taşlidere, 2015). Some research results prove the benefits of using simulations in learning physics, including the use of technology to improve understanding of the concepts of physics materials (Oymak \& Ogan-Bekiroglu, 2017). The effectiveness of using augmented reality in improving students' understanding of concepts is as good as hands-on activities (Wicaksono, Wasis, \& Madlazim, 2017). Student physics learning outcomes using technology are better than conventional activities in the laboratory (Civelek, Ucar, \& Ustunel, 2014).

Following the report above, it is necessary to advance investigation in accord the learning needs of physics that support the development of the $21^{\text {st }}$ century. The objective of this investigation is to provide student worksheets that are integrated by augmented reality to train higher-order thinking talents.

\section{METHOD}

This examination had the main objective, which was to produce products in the form of student worksheets that were implemented by 3D simulations, using augmented reality media.

\section{Method Research}

This examination was development research which tested the theories, concepts, or designs to generate new outputs or can improve current produce. This developmental investigation refers to a Dick \& Carey Model. This design is seen as organizing and 
producing a set of knowledge, models, experiences, and projects that lead, help and enhance the physical mental manners of students (Dick \& Carey, 2015). The Dick and Carey model has ten steps which distinguishing common training intentions, examining training, investigating learner features and knowledge set, formulating studying purposes, generating the evaluation of instruments following the references, elaborating learning approaches at school, advancing and producing learner worksheets, planning and generating formative evaluations, reviewing training programs, forming and improving summative evaluations (Pyatt \& Sims, 2012).

\section{Data Collection and Instrument}

The data collection method of this investigation used an assessment instrument. The product is tested for eligibility by media, material and learning experts. In addition to being tested for eligibility by experts, the product will be tested on teachers and students at school.

\section{Data Analysis}

After the data results have been obtained through validation and field test questionnaires from substance specialists, media masters, high school physics educators and learners, the next step is to analyze the data. This research focuses on developing teaching materials so that the data are analyzed using quantitative analysis techniques. Then the validation research results are calculated as follows.

$$
\text { percentage score }=\frac{\sum \text { acquisition score }}{\sum \text { maximum score }} \times 100 \%
$$

The percentage of scores obtained is then measured using a score interpretation for the value scale. Interpretations are shown as in Table 1.

Table 1. Interpretations of Feasibility Scales

\begin{tabular}{cc}
\hline Percentage & Interpretation \\
\hline $0 \%-20 \%$ & Extremely Poor \\
$21 \%-40 \%$ & Unsatisfactory \\
$41 \%-60 \%$ & Quite Satisfactory \\
$61 \%-80 \%$ & Satisfactory \\
$81 \%-100 \%$ & Extremely Satisfactory \\
\hline
\end{tabular}

Source: (Chiu, Dejaegher, \& Chao, 2015)

From the results of trials in school, the results of the pretest and posttest will be known whether the student's knowledge is increased or not after using the product developed by the research. To find out the improvement in learner training results, the gain test was used. Normalized $\mathrm{N}$-gain was used to provide a general description of the increase in learning outcomes between before and after learning (Sundayana, 2016). The $\mathrm{N}$-gain formula is explained in the following equation:

$$
\text { Gain }\langle g\rangle=\frac{\text { post test score - pre test score }}{\text { ideal score-pre test score }}
$$


The Gain results obtained are then written down in the interpretation of the scores into categories, as in Table 2.

Table 2. Table Gain Test N Score

\begin{tabular}{cc}
\hline Gain Score & Classification \\
\hline$(<\mathrm{g}>)<0,3$ & Poor \\
$0,3<(<\mathrm{g}>)<0,7$ & Medium \\
$(<\mathrm{g}>)>0,7$ & Tremendous \\
\hline
\end{tabular}

Source: (Srisawasdi \& Kroothkeaw, 2014)

\section{RESULT AND DISCUSSION}

The Student worksheet developed consists of nine compilation components classified into three stages of worksheet, namely the preceding, the practicum, and the post-practicum level. At the end of the application theory, learners were requested to investigate the label and carry out a 3-Dimensional simulation of the application of the theory of the practicum transferred using Google Cardboard and display the virtual lab. The simulation at the worksheet stage is illustrated in Figure 1.

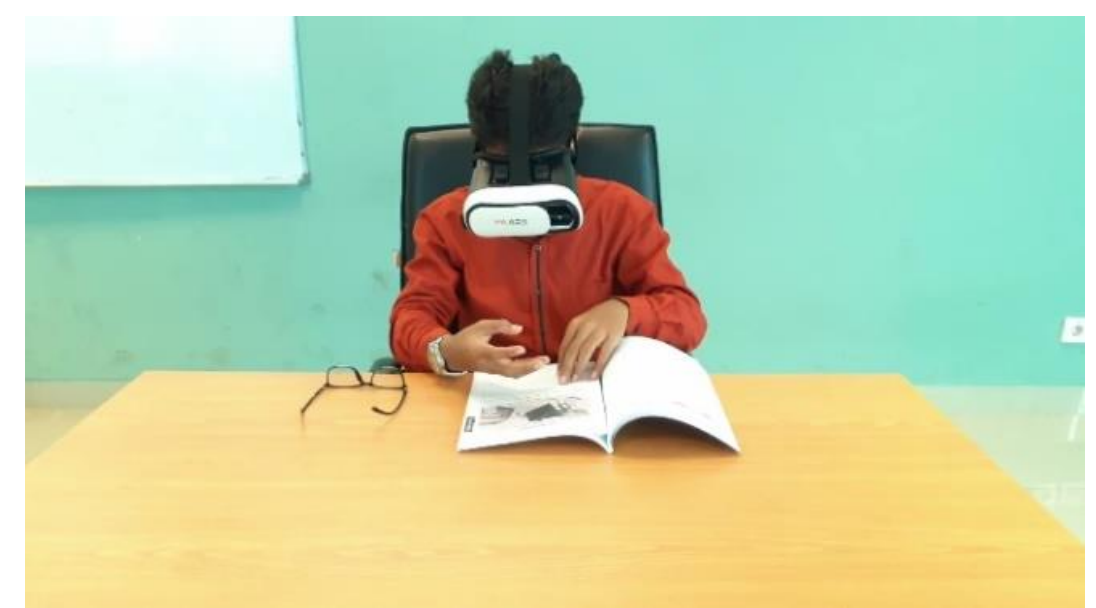

(a)

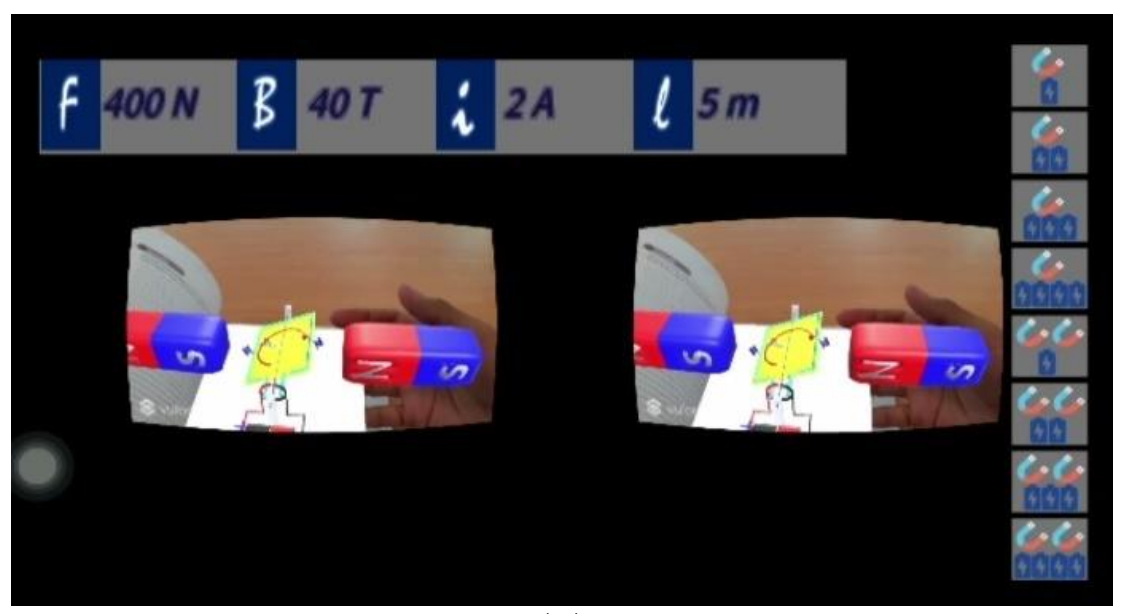

(b)

Figure 1. Worksheet Display Equipped with Augmented Physics' Lab 
In Figure 1 (a) demonstrates how to use the Augmented Physics' Lab application when using worksheet, Figure 1 (d) is a screenshot of a smartphone when using virtual reality glasses and displays a more real simulation in a simulated environment. This research intends to create product in the frame of student worksheet equipped with a augmented physics' lab to encourage high order thinking talents for high school learners in learning physics. To validate the products that have been developed, an assessment of the products developed as follows is carried out.

The validation test by the material expert is carried out through the assessment of the physical material validation test instrument sheet. This validation test instrument sheet contains 17 questions from 2 aspects, namely (1) Material Suitability, and (2) Material Consistency. The completion of the workability examination by material specialists obtained the results of the assessment of $95 \%$ with the interpretation of "Extremely Satisfactory " illustrated in Table 3.

Table 3. The Outcomes of Validation Tests by Material Experts

\begin{tabular}{llll}
\hline No & Aspect Measured & Percentage & Interpretation \\
\hline 1 & Material Suitability & $97 \%$ & Extremely Satisfactory \\
2 & Material Consistency & $93 \%$ & Extremely Satisfactory \\
\hline The & Rate of All Features Measured & $\mathbf{9 5 \%}$ & Extremely Satisfactory \\
\hline
\end{tabular}

Subsequently, the validation test was carried out by the Media Expert through an assessment given through the validation test instrument sheet by the media expert. This validation test instrument contains 55 questions from 5 aspects, namely (1) worksheet components, (2) design of worksheet contents, (3) typography of worksheet contents, (4) illustrations of worksheet contents, and (5) functioning of AR Application. The completion of the workability examination by media specialists achieved the outcomes of the assessment of 86.8\%, resulting "Extremely Satisfactory" illustrated in Table 4.

Table 4. The Outcomes of Validation Examination by Media Specialists

\begin{tabular}{llll}
\hline No & Aspect Measured & Percentage & Interpretation \\
\hline 1 & Worksheet component & $92 \%$ & Extremely Satisfactory \\
2 & Layout the contents of the worksheet & $88 \%$ & Extremely Satisfactory \\
3 & Typography of worksheet & $83 \%$ & Extremely Satisfactory \\
4 & Illustration contents of worksheet & $81 \%$ & Extremely Satisfactory \\
5 & The application function of AR & $90 \%$ & Extremely Satisfactory \\
\hline The Average of All Aspects Measured & $\mathbf{8 6 , 8 \%}$ & Extremely Satisfactory \\
\hline
\end{tabular}

Furthermore, the workability examination by the learning specialist was carried out. The assessment of the feasibility of learning is given through a validation test instrument sheet to the learning expert. This validation test instrument sheet contains 20 questions from 4 aspects, namely (1) Didactic Requirements, (2) Construction Requirements, (3) Technical Requirements, and (4) HOTS. The outcomes of the workability test by learning specialist, the percentage achieved was $81 \%$ by the interpretation of "Extremely Satisfactory" shown in Table 5. 
Table 5. The Outcomes of Validation Tests by Learning Experts

\begin{tabular}{llll}
\hline No & Aspect Measured & Percentage & Interpretation \\
\hline 1 & Didactic Requirements & $78 \%$ & Satisfactory \\
2 & Configuration Specifications & $83 \%$ & Extremely Satisfactory \\
3 & Mechanical Specifications & $78 \%$ & Satisfactory \\
4 & HOTS & $84 \%$ & Extremely Satisfactory \\
\hline The Rate of All Features Measured & $\mathbf{8 1 \%}$ & Extremely Satisfactory \\
\hline
\end{tabular}

The product trial was conducted by the teacher. The first stage of product testing was to the master. The product being tested is the student worksheet and the augmented physics'lab application. The results of the product trial evaluation by the teacher were indicated in Table 6.

Table 6. The Outcomes of Evaluation by Teacher

\begin{tabular}{llll}
\hline No & Aspect Measured & Percentage & Interpretation \\
\hline 1 & Material of worksheet & $99 \%$ & Very Good \\
2 & Display and typography of worksheets & $98 \%$ & Very Good \\
3 & Augmented physics' lab application & $97 \%$ & Very Good \\
\hline The Rate of All Features Measured & $\mathbf{9 8 \%}$ & Very Good \\
\hline
\end{tabular}

After the feasibility examination has been completed by experts, a pretest is conducted before the students are given practical materials. Furthermore, practicum is carried out using products that have been developed. Students will be challenged to solve problems on the worksheet elements that lead learners in elaborating ideas and obtaining the mathematical equations required to answer the posttest. Then posttests were managed to attain the improvement in students' understanding. The outcomes of the N-gain examination were illustrated in Table 7.

Tabel 7. N-gain Result

\begin{tabular}{ccc}
\hline Pretest & Posttest & N-gain \\
\hline 23,5 & 72,45 & 0,64 \\
\hline
\end{tabular}

This investigation intentions to create a student worksheet equipped with a augmented physics' lab to train high order thinking talents for high school learners in studying physics. The product produced is a practicum worksheet that can display 3dimensional animation at the student worksheet stage. Worksheet which has been developed subsequently enters the evaluation stage by experts to determine the feasibility value. The workability examination was carried out by material, media, and learning specialist with instruments in accordance with the characteristics of worksheet eligibility. The material which had a validation obtained an number percentage of $95 \%$ in "very good" interpretation. Meanwhile, the outcomes of the feasibility examination by media specialist achieved a percentage rate of $86.8 \%$ in a "very good" interpretation. Also the results of the feasibility test by learning experts reached an average assessment achievement of $81 \%$ with "very good" interpretation. 
After the feasibility test is conducted by an expert, worksheet is then trialled to users, namely by teachers and students. The product trial results obtained by teachers reached a percentage achievement of $98 \%$, Following to educator users worksheet, the elements comprised in the worksheet that was implemented by AR were classified as extremely feasible. Then the students are tested using practical products that are developed. Pretest and posttest conducted show the effect of the use of applications on students. Normalized gain examination outcomes received by 0.64 which represented an improvement in the capacity of pupils at the common level. Following these outcomes, it can be decided that there was an improvement in learner training outcomes after using a practical worksheet provided by augmented physics' lab.

Investigation on learner worksheets has been taken already to advance learner worksheets in order to study the high-level thinking talents of high school pupils, but the research still has shortcomings in presenting stimulus for students and is not equipped with technology (Bulan, Nengah, \& Ertikanto, 2015). Worksheet has also been developed with augmented reality, but in this study there were deficiencies in the efficiency of smartphone use because they had to be grasped throughout the practicum (Anggraeni, Rosidin, \& Suana, 2016). Thus, when associated by the earlier related investigation, outputs produced to exercise higher-order thinking abilities in Pratiwi study were more interesting (Pratiwi, Suyanto, \& Wahyudi, 2014) because they were outfitted with a motive that can be observed and assist learners in managing practical activity. The development of this augmented reality application is also a form of advanced research of augmented reality that has been integrated with interactive augmented reality on the use of smartphones on solar system material (Sumardani, Wulandari, \& Doriza, 2019) and further forms of augmented reality marker research on electromotive force (F Bakri, Sumardani, \& Muliyati, 2019).

\section{CONCLUSION}

Advancement of the augmented physics' lab to encourage the talent to study at a high level has reached the criteria extremely great in terms of substance, tools, and training aspects, as well as meeting the criteria very well in product trials by teachers. Meanwhile, trials of increasing students through pretest and posttest obtained results in an development in the talent to think of high-level learners in the medium category. These results indicate that the augmented physics' lab is feasible to be used in physics practicum material on magnetic field material, but the research still has shortcomings in presenting better stimulus for students.

\section{REFERENCES}

Anggraeni, F., Rosidin, U., \& Suana, W. (2016). Perbandingan Hasil Belajar Menggunakan LKS Berbasis Laboratorium Virtual dengan LKS Konvensional. Jurnal Pembelajaran Fisika, 4(1).

Asyhar, N., Mujasam, Yusuf, I., \& Widyaningsih, S. W. (2017). Pengembangan Media Pembelajaran Fisika Berbasis Multimedia Interaktif pada Materi Gerak Parabola di SMA. Prosiding Seminar Nasional, 3(1), 18-27.

Bakri, F., Sumardani, D., \& Muliyati, D. (2019). Integrating augmented reality into worksheets: Unveil learning to support higher-order thinking skills. AIP 
Conference Proceedings, 2169(1), 20012.

Bakri, F., Sumardani, D., \& Muliyati, D. (2019a). The 3D simulation of Lorentz Force based on augmented reality technology. Journal of Physics: Conference Series, 1402(6), 66038.

Bakri, F., Sumardani, D., \& Muliyati, D. (2019b). The augmented reality application for simulating electromotive force concept. Journal of Physics: Conference Series, 1402(6), 66039.

BSNP. (2019). Buku Saku Ujian Nasional 2019. Jakarta: Badan Standar Nasional Pendidikan.

Bulan, S. N., Nengah, M., \& Ertikanto, C. (2015). Pengaruh Kemampuan Inkuiri terhadap Hasil Belajar Fisika Berbantuan Virtual Laboratory. Jurnal Pembelajaran Fisika, 3(3).

Chiu, J. L., Dejaegher, C. J., \& Chao, J. (2015). The effects of augmented virtual science laboratories on middle school students' understanding of gas properties. Computers and Education, 85, 59-73.

Civelek, T., Ucar, E., \& Ustunel, H. (2014). Effects of a Haptic Augmented Simulation on K-12 Students' Achievement and their Attitudes towards Physics. Eurasia J. Math. Sci. \& Tech. Ed, 10(6), 565-574.

Deacon, C., \& Hajek, A. (2010). Student Perceptions of the Value of Physics Laboratories. International Journal of Science Educational, 1-35.

Dick, W., \& Carey, L. (2015). The Systematic Design of Instruction (8th ed.). The United States of America: Pearson Education, Inc.

Hodson, D. (2006). The Role of Assessment in the "Curriculum Cycle": a survey of science department practice. Research in Science \& Technological Education, 4(1), $7-17$.

Hofstein, A., \& Lunetta, V. N. (2013). The Laboratory in Science Education: Foundations for the Twenty-First Century. Lab. in Science Edu, 29-54.

Majzub, R. M. (2013). Teacher Trainees' Self Evaluation during Teaching Practicum. Procedia - Social and Behavioral Sciences, 102(1), 195-203.

Malik, A., Handayani, W., \& Nuraini, R. (2015). Model Praktikum Problem Solving Laboratory untuk Meningkatkan Keterampilan Proses Sains Mahasiswa. Prosiding Simposium Nasional Inovasi Dan Pembelajaran Sains 2015 (SNIPS 2015), 193196.

Noss, R. (2012). 21 st Century Learning for 21 st Century Skills : What Does It Mean and How Do We Do It? 7th European Conference on Technology Enhanced Learning, 3-5.

Oymak, O., \& Ogan-Bekiroglu, F. (2017). Comparison of Students' Learning and Attitudes in Technology Supported and Laboratory Based Environments. The Eurasia Proceedings of Educational \& Social Sciences (EPESS), 6, 109-113.

Permana, A. H., Bakri, F., \& Chaerunnisa, M. (2019). Buku IPA dengan Teknologi Augmented Reality: Melatih Kemampuan Berpikir Kritis Siswa SMP Kelas VII. Prosiding Seminar Nasional Fisika (E-Journal), 8, 233-238.

Pratiwi, M., Suyanto, E., \& Wahyudi, I. (2014). Pengembangan Suplemen Pembelajaran Fisika Gelombang Elektromagnetik Cahaya Sebagai Partikel Memanfaatkan Virtual Laboratorium. Jurnal Pembelajaran Fisika, 3(3).

Putri, A., Sumardani, D., Rahayu, W., \& Hajizah, M. N. (2020). Kemampuan Berpikir 
Kritis Matematis Menggunakan Model Generative Learning dan Connecting, Organizing, Reflecting, Extending (CORE). AKSIOMA: Jurnal Program Studi Pendidikan Matematika, 9(1), 108-117.

Putri, D. H., Sutarno, \& Risdianto, E. (2014). Profil Peralatan dan Keterlaksanaan Praktikum Fisika SMA di Wilayah Miskin Provinsi Bengkulu. Jurnal Exacta, 12(1), 1-6.

Pyatt, K., \& Sims, R. (2012). Virtual and Physical Experimentation in Inquiry-Based Science Labs. J Sci Educ Tech, 21(2), 133-147.

Ramalisa, Y., \& Pasaribu, F. T. (2015). Meningkatkan Kemampuan Pemecahan Masalah Matematika dengan Menggunakan Pendekatan Matematika Realistik. Prosiding Semirata 2015 Bidang MIPA BKS-PTN Barat, 325-336.

Salsabila, E., Rahayu, W., Kharis, S. A., \& Putri, A. (2019). Analysis of Mathematical Literacy on Students' Metacognition in Conic Section Material. Journal of Physics: Conference Series, 1417(1), 1-8.

Srisawasdi, N., \& Kroothkeaw, S. (2014). Supporting Students ' Conceptual Development of Light Refraction by Simulation-based Open Inquiry with Dualsituated Learning Model. J. Comput. Educ., 1(1), 49-79.

Sumardani, D., Putri, A., Saraswati, R. R., Muliyati, D., \& Bakri, F. (2020). Virtual Reality Media: The Simulation of Relativity Theory on Smartphone. Formatif: Jurnal Ilmiah Pendidikan MIPA, 10(1), 13-24.

Sumardani, D., Saraswati, R. R., Putri, A., Bakri, F., \& Muliyati, D. (2020). System Implementation of Augmented Reality Application in Student Worksheet. JURNAL INFORMATIKA, 8(1), 10-18.

Sumardani, D., Wulandari, A., \& Doriza, S. (2019). Penerapan Teknologi Augmented Reality pada Media Pembelajaran Poster Tatasurya. In Prosiding Seminar Nasional Fisika (E-Journal) (Vol. 8, pp. 451-456).

Sundayana, R. (2016). Statistika Penelitian Pendidikan. Bandung: Penerbit Alfabeta.

Taşlidere, E. (2015). A Study Investigating the Effect of Treatment Developed by Integrating the 5E and Simulation on Pre- service Science Teachers' Achievement in Photoelectric Effect. Eurasia Journal of Mathematics, Science \& Technology Education, 1-16.

Tobin, K. (1990). Activities : In Pursuit of Better Questions and Answers to Improve Learning. School Science and Mathematics, 90(5), 403-418.

Wicaksono, I., Wasis, \& Madlazim. (2017). The Effectiveness of Virtual Science Teaching Model (VS-TM) to Improve Student's Scientific Creativity and Concept Mastery on Senior High School Physics Subject. Journal of Baltic Science Education, 16(4), 549-561.

Yusuf, I., Widyaningsih, S. W., \& Purwati, D. (2015). Pengembangan Perangkat Pembelajaran Fisika Modern Berbasis Media Laboratorium Virtual Berdasarkan Paradigma Pembelajaran Abad 21 dan Kurikulum 2013. Pancaran, 4(2), 189-200. 